\title{
MEMPELAJARI KONSENTRASI PURE BUAH SEMANGKA (Citrullus lanatus) TERHADAP KARAKTERISTIK ES KRIM
}

\author{
The Concentration of Watermelon Pure (Citrullus lanatus) \\ on Ice Cream Characteristics
}

\author{
Efriliani Sekartini, Dewi Nur Azizah \\ Program Studi Pendidikan Teknologi Agroindustri, Fakultas Pendidikan Teknologi dan Kejuruan \\ Universitas Pendidikan Indonesia, Bandung, Indonesia \\ E-mail: efrilianisekartini@upi.edu
}

\begin{abstract}
ABSTRAK
Es krim merupakan produk olahan susu yang banyak digemari oleh masyarakat terutama anak-anak karena rasanya yang manis, teksturnya lembut, dan mempunyai nilai gizi tinggi. Es krim termasuk golongan pangan fungsional. Sejauh ini buah semangka jarang dimanfaatkan selain hanya dikonsumsi dalam bentuk segar. Oleh karena itu, diperlukan inovasi pangan fungsional, yaitu es krim pure buah semangka. Semangka memiliki warna daging buah yang merah karena adanya zat likopen dan berfungsi sebagai pewarna alami makanan serta memiliki manfaat bagi kesehatan. Berkaitan dengan hal tersebut telah dilakukan penelitian dengan tujuan mengetahui karakteristik es krim buah semangka dan konsentrasi pure buah semangka yang tepat untuk menghasilkan es krim dengan karakteristik yang baik dan disukai oleh panelis. Penelitian ini menggunakan metode percobaan secara deskriptif dengan satu faktor, yaitu konsentrasi pure buah semangka yang terdiri dari 8 perlakuan $(0 \%, 10 \%, 20 \%, 30 \%$. 40\%. 50\%, 60\%, 70\%, dan $80 \%)$. Hasil penelitian menunjukkan bahwa karakteristik es krim pure buah semangka yang dihasilkan memiliki warna merah muda, aroma semangka, tekstur kasar, dan rasa manis khas semangka serta es krim dengan penambahan pure buah semangka $60 \%$ adalah yang paling diterima oleh panelis.
\end{abstract}

Kata kunci: buah semangka, es krim, pure

\begin{abstract}
Ice cream is a dairy product that is likes by people, especially children because of its sweet taste, soft texture, and high nutritional value. Ice cream is a functional food group. So far, watermelon is only being consumed in fresh form. Therefore, a functional food innovation is required, one of them is ice cream with watermelon puree. Watermelon has a red flesh color due to lycopene exist and functions as a natural food coloring agent and has health benefits. In this regard, research has been carried out with the aim of knowing the characteristics of watermelon ice cream and the proper concentration of watermelon puree to produce ice cream with good characteristics and is liked by the panelists. This study used a descriptive experimental method with one factor, namely concentrate watermelon puree consisting with 8 treatments $(0 \%, 10 \%, 20 \%, 30 \% .40 \% .50 \%, 60 \%, 70 \%$, and $80 \%)$. The results showed that the characteristics of watermelon puree ice cream produced had a pink color, watermelon aroma, rough texture, and a typical sweetness of watermelon and ice cream with the addition of $60 \%$ watermelon puree was the most accepted by the panelists.
\end{abstract}

Keywords: ice cream, pure, watermelon 


\section{PENDAHULUAN}

Menurut Standar Nasional Indonesia (SNI 01-3713-1995), es krim merupakan makanan semi padat yang dibuat dengan cara pembekuan tepung es krim atau campuran susu, lemak hewani atau lemak nabati, gula, dan dengan atau tanpa bahan makanan lain dan bahan makanan yang diizinkan seperti dapat ditambahkan buah-buahan dan zat pemberi warna. Es krim merupakan produk olahan susu yang banyak digemari oleh masyarakat, terutama anak-anak karena rasanya yang manis, teksturnya lembut, dan mempunyai nilai gizi tinggi (Fitrahdini, dkk., 2010). Es krim dapat dikatakan sebagai salah satu jenis makanan yang sangat populer di dunia dan konsumen es krim tidak hanya terbatas pada golongan anak-anak, tetapi sudah meluas di kalangan remaja, dewasa, dan orang tua (Puspitarini, 2012). Es krim juga sangat baik untuk kesehatan karena kaya akan nutrisi dan termasuk dalam golongan produk pangan fungsional.

Pangan fungsional sendiri merupakan pangan olahan yang mengandung satu atau lebih komponen pangan yang berdasarkan kajian ilmiah yang mempunyai fungsi fisiologis tertentu di luar fungsi dasarnya, tidak membahayakan, dan bermanfaat bagi kesehatan (BPOM, 2011). Jika dilihat dari permintaan masyarakat terhadap produk pangan fungsional yang semakin meningkat. Global Industry Analysis memprediksi pertumbuhan produk pangan fungsional mencapai USD 130 miliar pada tahun 2015, sementara terdapat 42\% produk yang diluncurkan secara global dengan memberikan klaim kesehatan (Innova Market Insights, 2013).

Pangan fungsional merupakan pangan yang memiliki efek kesehatan lain di samping efek zat gizinya. Nilai gizi es krim sangat tergantung dari nilai gizi bahan bakunya. Oleh karena itu, untuk membuat es krim yang bermutu tinggi, nilai gizi bahan baku perlu diketahui dengan pasti.

Buah semangka memiliki kandungan rendah kalori dan air sebanyak $93,4 \%$, protein $0,5 \%$, karbohidrat $5,3 \%$, lemak $0,1 \%$, serat $0,2 \%$, abu $0,5 \%$, dan vitamin $(A, B$, dan $C)$ dengan kandungan vitamin $\mathrm{C}$ sebesar $6 \mathrm{mg}$ per $100 \mathrm{~g}$ bahan. Selain itu, buah semangka memiliki daya tarik khusus pada bagian warna daging yang merah dan konsistensinya yang lemah, berair banyak, sangat merangsang selera untuk mencicipinya.

Sejauh ini buah semangka jarang dimanfaatkan, melainkan hanya dikonsumsi dalam bentuk segar bukan sebagai bahan dasar suatu produk pangan. Oleh karena itu, diperlukan inovasi pangan fungsional seperti es krim semangka. Buah semangka memiliki warna daging buah yang merah. Warna merah tersebut dapat digunakan sebagai pewarna pada produk olahan, salah satunya es krim. Selama ini pewarna es krim yang digunakan merupakan pewarna sintesis. Dengan digunakannya semangka pada es krim, maka diharapkn es krim yg dihasilkan memiliki warna dan kandungan gizi yang lebih baik. Jika dilihat dari banyaknya manfaat es krim dan buah semangka, maka akan dilakukan penelitian dengan judul "Mempelajari Konsentrasi Pure Buah Semangka (Citrullus lanatus) Terhadap Karakteristik Es Krim". Penelitian ini bertujuan untuk mempelajari konsentrasi pure buah semangka terhadap karakteristik es krim dan mengetahui konsentrasi pure buah semangka yang tepat untuk menghasilkan es krim dengan karakteristik baik dan disukai oleh panelis.

\section{METODE PENELITIAN}

Penelitian ini menggunakan metode percobaan secara deskriptif dengan satu faktor, yaitu konsentrasi pure buah semangka yang terdiri dari 8 perlakuan. Perlakuan yang diberikan, yaitu $0 \%, 10 \%, 20 \%, 30 \%, 40 \%, 50 \%, 60 \%$, dan $70 \%$. 


\section{Alat dan bahan}

Alat yang digunakan dalam penelitian ini adalah pisau, talenan, wadah, mixer, blender, freezer, timbangan, kemasan, dan stopwatch. Bahan yang digunakan dalam penelitian ini adalah daging buah semangka, susu UHT, gula, CMC, whip cream, dan SP emulsifier.

\section{Tahapan Penelitian}

Pada penelitian ini dilakukan dua tahapan, yaitu pembuatan pure buah semangka dan pembuatan es krim semangka.

\section{Pembuatan Pure Buah Semangka}

Pembuatan pure buah semangka ini menggunakan daging buah semangka merah yang diawali dengan proses pengupasan semangka. Proses ini dilakukan untuk memisahkan daging buah semangka yang dijadikan pure dengan biji dan kulit buah semangka. Selanjutnya penimbangan daging buah semangka dan proses pengecilan ukuran, yaitu pemotongan untuk mempercepat dan mempermudah proses penghancuran daging buah semangka. Setelah itu proses penghancuran dengan menggunakan blender selama \pm 3 menit. Diagram alir pembuatan pure buah semangka dapat dilihat pada

\section{Gambar 1.}

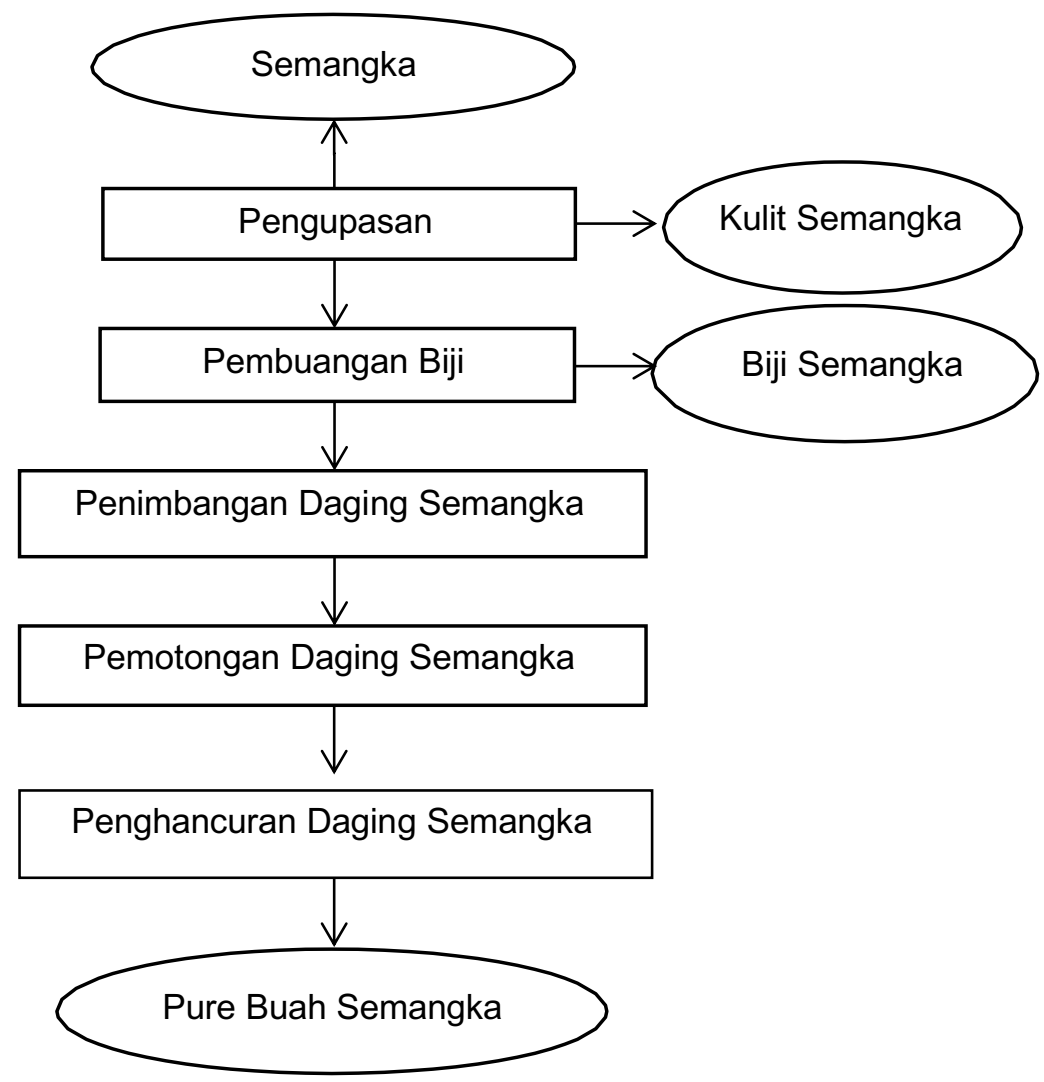

Gambar 1. Diagram Proses Pembuatan Pure Buah Semangka Sumber: Modifikasi dari Winarno (1997) 


\section{Pembuatan Es Krim Pure Buah Semangka}

Pembuatan es krim buah semangka ini dilakukan melalui beberapa tahapan, yaitu proses pasteurisasi pada susu yang bertujuan untuk membunuh mikroorganisme yang bersifat patogen. Pasteurisasi yang digunakan dalam pembuatan es krim semangka ini yaitu High Temperature Short Time (HTST) dengan suhu $72^{\circ} \mathrm{C}$ selama 15 detik. Selanjutnya proses pencampuran 1, yaitu diawali dengan gula pasir dan $C M C$ serta dilanjutkan dengan bahan lainnya, seperti whipping cream dan SP emulsifier. Setelah itu, dilakukan proses homogenisasi menggunakan mixer selama 15 menit. Selanjutnya dilakukan pencampuran 2 yang diawali dengan adonan es krim pada tahap sebelumnya ditambahkan dengan pure buah semangka sesuai konsentrasi dan dilakukan homogenisasi selama 5 menit. Tahap selanjutnya, yaitu pengemasan es krim menggunakan wadah berbahan plastik dan penyimpanan es krim dalam freezer dengan suhu $-18^{\circ} \mathrm{C}$. Diagram alir pembuatan es krim pure buah semangka dapat dilihat pada Gambar 2.

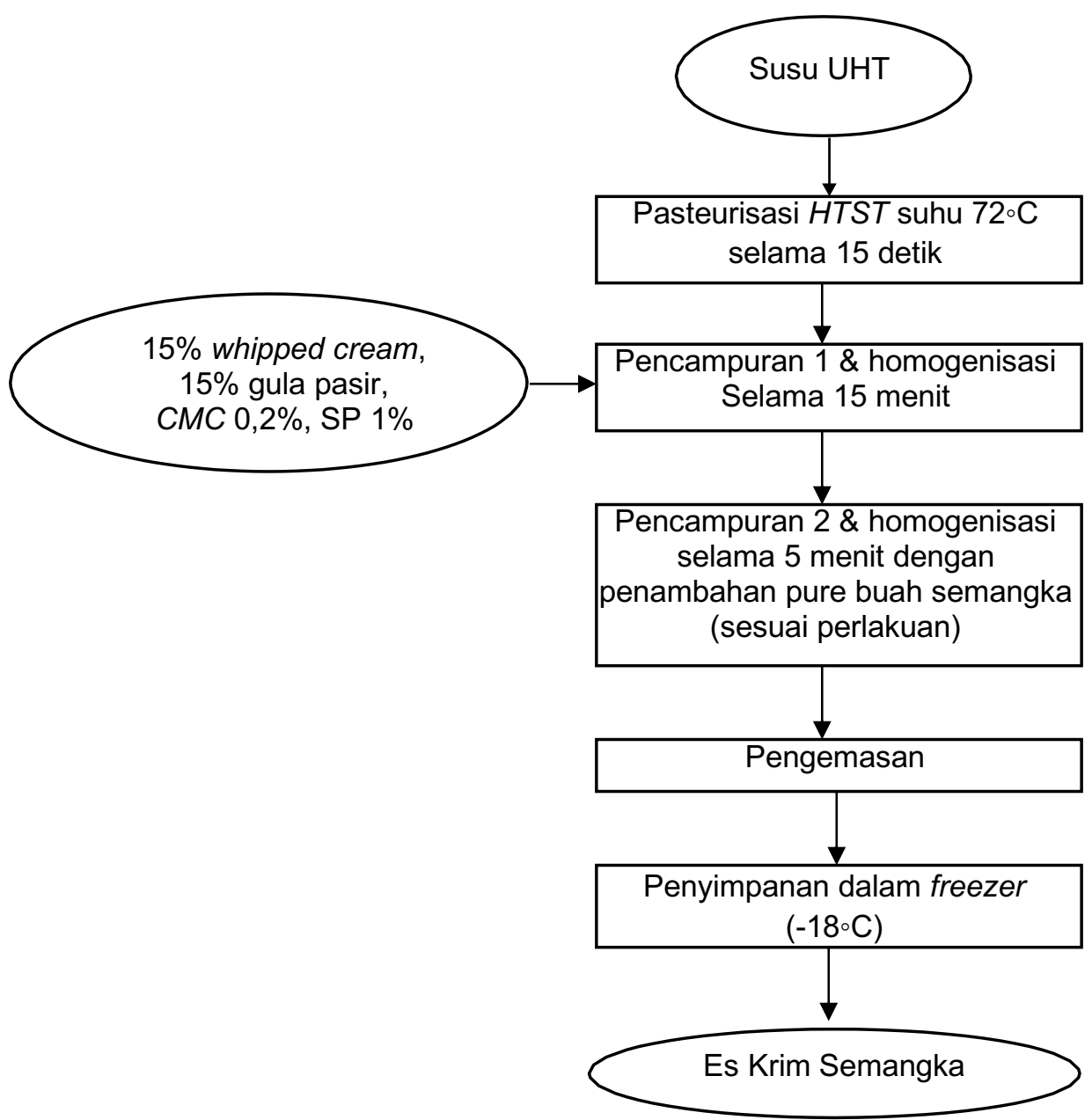

Gambar 2. Diagram Alir Pembuatan Es Krim Semangka Sumber: Modifikasi dari Hendriani (2005) 
HASIL DAN PEMBAHASAN

Karakteristik Es Krim Buah Semangka

Tabel 1. Karakteristik Es Krim Pure Buah Semangka

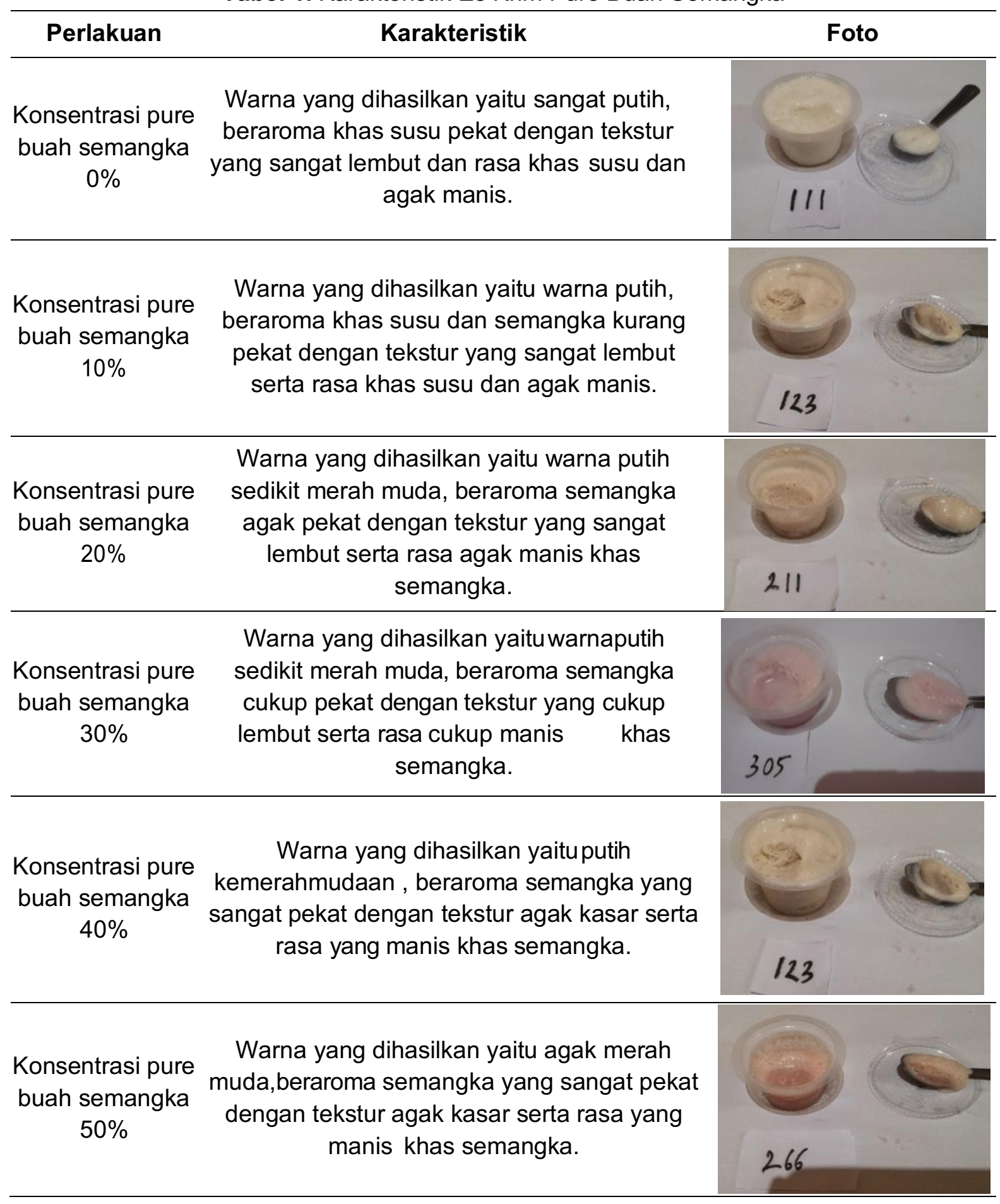




\section{Perlakuan}

Konsentrasi pure buah semangka $60 \%$
Warna yang dihasilkan yaitu cukup merah muda,beraroma semangka yang sangat pekat dengan tekstur cukup kasar serta rasa yang manis khas semangka.

\section{Foto}

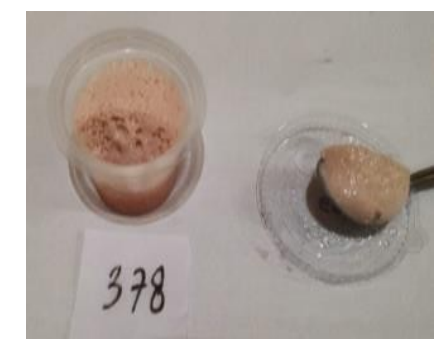

Konsentrasi pure buah semangka $70 \%$
Warna yang dihasilkan yaitu merah muda, beraroma semangka yang sangat pekat dengan tekstur cukup kasar serta rasa yang manis khas semangka.

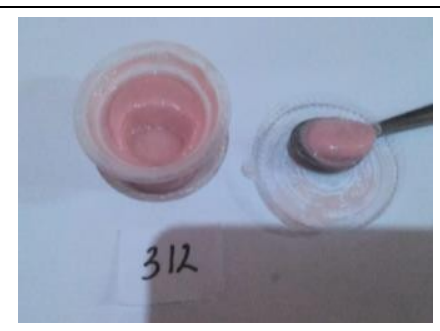

\section{Parameter Warna}

Pada Tabel 1 menunjukkan bahwa es krim tanpa pure buah semangka (kontrol) atau perlakuan $0 \%$ memiliki warna sangat putih, es krim dengan perlakuan $10 \%$ memiliki warna putih, es krim dengan perlakuan $20 \%$ dan $30 \%$ tidak terlalu memiliki perbedaan, yaitu warna putih dengan sedikit kemerahmudaan, es krim dengan perlakuan $40 \%$ memiliki warna putih kemerahmudaan, es krim dengan perlakuan $50 \%$ memiliki warna agak merah muda, dan es krim dengan perlakuan $60 \%$ memiliki warna cukup merah muda yang cukup berbeda dengan perlakuan sebelumnya, serta es krim dengan perlakuan $70 \%$ memiliki warna merah muda. Semakin besar konsentrasi pure buah semangka yang ditambahkan, warna es krim semakin merah muda. Hal ini disebabkan oleh penambahan pure semangka yang semakin pekat.

Likopen adalah salah satu senyawa fitokimia dari golongan karotenoid penghasil utama pemberi pigmen berwarna merah pada semangka. Semakin tua atau matang semangka, warna semakin merah dikarenakan kadar likopen yang semakin tinggi. Hal ini dapat dijelaskan bahwa warna merupakan akibat dari adanya ikatan rangkap terkonjugasi, yaitu semakin banyak ikatan rangkap terkonjugasi dalam molekul, pita serapan utama makin bergeser ke daerah panjang gelombang yang lebih tinggi, akibatnya rona makin merah (deMan, 1997).

Kadar likopen pada semangka cukup tinggi, yaitu 48,8\% (Tadmor, et. al., 2005). Likopen merupakan antioksidan yang sangat kuat dan juga merupakan senyawa penting karena penggunaanya sebagai pewarna alami makanan dan memiliki manfaat bagi kesehatan (Nur,S.R dkk., 2015). Pada pembentukan likopen, suhu mempunyai peranan penting, jika suhu naik, maka likopen semakin banyak terbentuk (Sari, dkk., 2007).

\section{Parameter Aroma}

Kandungan senyawa pada suatu bahan terlarut dalam air dan lemak mampu menghasilkan aroma. Indera penciuman berfungsi mendeteksi aroma yang menguap bersama senyawa di udara (Nurwantoro, 2009). 
Pada Tabel 1 menunjukkan bahwa es krim tanpa pure buah semangka (kontrol) atau perlakuan $0 \%$ memiliki aroma khas susu yang sangat pekat, es krim dengan perlakuan $10 \%$ memiliki aroma susu dan semangka yang masih kurang pekat, es krim dengan perlakuan $20 \%$ memiliki aroma semangka yang mulai agak pekat, es krim dengan perlakuan $30 \%$ memiliki aroma semangka yang sudah cukup pekat, es krim dengan perlakuan $40 \%, 50 \%$, $60 \%$, dan $70 \%$ memiliki aroma semangka yang sangat pekat. Semakin tinggi konsentrasi pure buah semangka, semakin tercium aroma semangka. Hal ini sesuai dengan kententuan SNI nomor 01-3713-1995 tentang es krim, yaitu memiliki aroma yang normal sesuai dengan bahan yang digunakan dalam pembuatan es krim.

Aroma dipengaruhi oleh beberapa faktor, salah satunya adalah gula. Gula adalah pemanis yang umum digunakan pada es krim dan juga meningkatkan aroma es krim (Marshall dan Arbuckle, 1996).

\section{Parameter Tekstur}

Salah satu parameter mutu yang sangat berperan dalam menampilkan karateristik es krim adalah tekstur. Hal ini mempunyai hubungan dengan rasa pada waktu mengunyah bahan tersebut. Tekstur es krim yang ideal adalah halus dan partikel padatan terlalu kecil untuk dapat dirasakan di mulut. Tekstur berpasir (coarseness) dapat menunjukkan bahwa kristal besar dengan ukuran yang tidak seragam atau sel udara terlalu besar (Szcensniak, 1998).

Pada Tabel 1 menunjukkan bahwa es krim tanpa pure buah semangka (kontrol) atau perlakuan $0 \%, 10 \%$, dan $20 \%$ memiliki tekstur yang sama, yaitu lembut saat di mulut, es krim dengan perlakuan $30 \%$ memiliki tekstur yang cukup lembut atau tingkat kelembutan pada perlakuan ini sudah mulai menurun, es krim dengan perlakuan $40 \%$ dan $50 \%$ memiliki tekstur yang sudah mulai agak kasar, dan es krim dengan perlakuan $60 \%$ dan $70 \%$ memiliki tekstur yang sudah cukup terasa kasar. Tekstur es krim tanpa pure buah semangka memiliki perbedaan dengan es krim yang ditambahkan pure buah semangka. Es krim tanpa pure buah semangka memiliki tekstur yang lebih halus dibandingkan dengan es krim yang ditambahkan pure buah semangka. Semakin tinggi konsentrasi pure buah semangka, semakin kasar tekstur es krim yang dihaslkan.

Menurut Widiantoko (2011), tekstur yang lembut dipengaruhi oleh bahan-bahan yang dicampurkan, pengolahan, dan penyimpanan. Tekstur es krim tergantung dari ukuran, bentuk, dan ukuran partikel padatan penyusun es krim. Tekstur yang ideal bagi es krim adalah tekstur yang sangat halus dan ukuran partikel padatan yang sangat kecil, sehingga tidak terdeteksi dalam mulut.

\section{Parameter Rasa}

Rasa merupakan hal yang sangat diperhatikan dalam pembuatan suatu produk. Rasa merupakan rangsangan yang ditimbulkan oleh bahan yang dimakan, terutama dirasakan oleh indera pengecap. Rasa pada suatu makanan dipengaruhi oleh penggunaan bahan dasar. Suatu produk dapat diterima oleh konsumen apabila memiliki rasa yang sesuai dengan yang diinginkan (Kartika, dkk., 1988). 
Pada Tabel 1 menunjukkan bahwa es krim tanpa pure buah semangka (kontrol) atau perlakuan $0 \%$ dan perlakuan $10 \%$ tidak terlalu jauh berbeda, yaitu rasa khas dari susu dan manis, es krim dengan perlakuan $20 \%$ memiliki rasa agak manis khas semangka, es krim dengan perlakuan $30 \%$ memiliki rasa yang cukup manis khas semangka, dan es krim dengan perlakuan $40 \%, 50 \%, 60 \%$, dan $70 \%$ memiliki rasa yang manis khas semangka.

Rasa manis pada es krim mengalami peningkatan seiring meningkatnya konsentrasi pure buah semangka. Rasa es krim sudah sesuai dengan ketentuan SNI 01-3713-1995 tentang es krim, yaitu memiliki rasa yang normal sesuai dengan bahan yang digunakan dalam pembuatan es krim. Pada es krim dengan konsentrasi pure buah semangka $10 \%$, rasa yang terdeteksi adalah agak manis yang berasal dari bahan utama, yakni sukrosa. Bahan sukrosa yang paling banyak digunakan adalah gula pasir. Selain gula yang ditambahkan sebagai bahan pemanis, gula pada es krim juga termasuk laktosa yang berasal dari susu (Padaga dan Sawitri, 2005). Es krim dengan konsentrasi pure buah semangka $30 \%, 40 \%, 50 \%, 60 \%$, dan $70 \%$ yang terdeteksi adalah rasa manis yang berasal dari kombinasi bahan utama dan bahan tambahan. Tingginya konsentrasi pure buah semangka dapat menyebabkan rasa manis pada es krim (Whitting, 1995).

\section{Pengujian Organoleptik Es Krim}

Uji organoleptik atau uji hedonik merupakan cara pengujian dengan menggunakan indera manusia sebagai alat utama untuk pengukuran daya penerimaan terhadap produk. Uji organoleptik dengan menggunakan metode hedonik dilakukan terhadap parameter warna, aroma, tekstur, dan rasa pada es krim.

Setiap tingkat memiliki nilai, yaitu nilai 1 untuk sangat tidak suka, nilai 2 untuk tidak suka, nilai 3 untuk biasa, nilai 4 untuk suka, dan nilai 5 untuk sangat suka. Nilai rata-rata pengujian hedonik bakso ayam dapat dilihat pada Gambar 3.

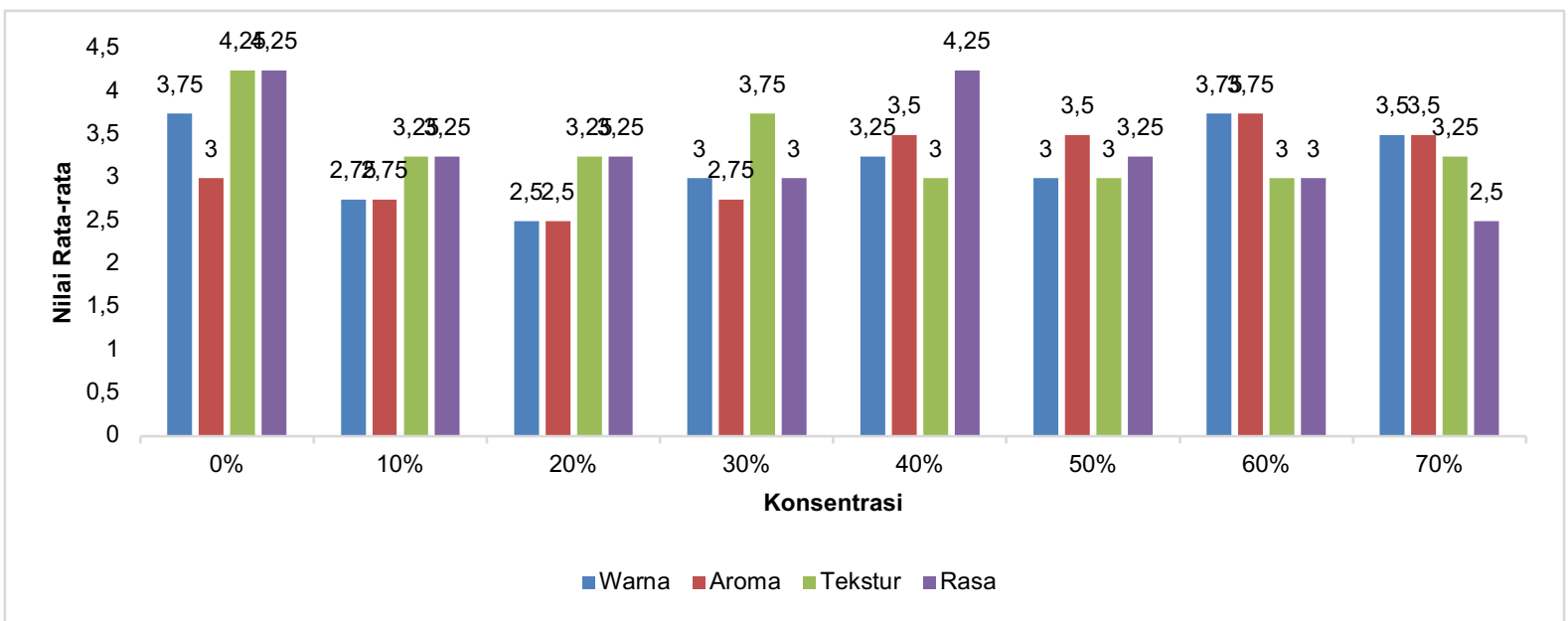

Gambar 3. Nilai Rata-rata Pengujian Hedonik Es Krim 


\section{Parameter Warna}

Umumnya konsumen memilih produk pangan sangat bergantung pada beberapa faktor, antara lain cita rasa, warna, aroma, tekstur, dan nilai gizinya. Parameter warna merupakan pertimbangan pertama panelis untuk memilih suatu produk bahan pangan sebelum mempertimbangkan parameter yang lain. Penampakan warna es krim pada penelitian ini memperlihatkan es krim dengan warna putih hingga merah muda. Hasil uji hedonik panelis terhadap parameter warna yang paling baik terdapat pada es krim tanpa pure semangka atau kontrol dan konsentrasi pure buah semangka $60 \%$ dengan nilai 3,75 (Gambar 3).

\section{Parameter Aroma}

Aroma merupakan salah satu parameter yang mempengaruhi terhadap persepsi rasa enak dari suatu produk. Pada industri pangan, uji terhadap aroma dianggap penting karena dengan cepat dapat memberikan penilaian minat konsumen terhadap hasil produksinya (Soekarto, 1995). Aroma dalam es krim merupakan kombinasi cita rasa dan bau (aroma), yang diciptakan untuk memenuhi selera konsumen (Padaga dan Sawitri, 2005). Pada umumnya aroma dan rasa merupakan satu kesatuan yang saling menunjang karena hal pertama yang diperhatikan oleh konsumen saat membeli es krim adalah aroma dan rasanya. Hasil uji hedonik panelis terhadap parameter aroma yang paling baik terdapat pada es krim dengan konsentrasi pure buah semangka 60\% dengan nilai 3,75 (Gambar 3).

\section{Parameter Tekstur}

Selain warna dan aroma, tekstur es krim juga sangat berpengaruh terhadap kesukaan konsumen. Tekstur merupakan sifat fisik yang ditimbulkan oleh elemen struktural bahan pangan yang dapat dirasakan olah perabaan (Purnomo, 1995). Hasil uji hedonik panelis terhadap parameter tekstur yang paling baik terdapat pada es krim tanpa pure semangka atau kontrol dan konsentrasi pure buah semangka 30\% dengan nilai 3,75 (Gambar 3). Panelis lebih menyukai es krim yang lembut dan relatif mudah meleleh di dalam mulut.

\section{Parameter Rasa}

Rasa merupakan salah satu faktor penentu mutu bahan makanan. Flavor atau rasa sebagai rangsangan yang ditimbulkan oleh bahan yang dimakan, yang dirasakan oleh indera pengecap atau pembau, serta rangsangan lainnya seperti perabaan dan penerimaan derajat panas oleh mulut (DeMan, 1997). Hasil uji hedonik panelis terhadap parameter rasa yang paling baik terdapat pada es krim tanpa pure semangka atau kontrol dan konsentrasi pure buah semangka $40 \%$ dengan nilai 4,25 (Gambar 3).

\section{KESIMPULAN}

Berdasarkan hasil penelitian dan pembahasan, maka dapat diambil kesimpulan sebagai berikut:

1. Karakteristik es krim pure buah semangka yang dihasilkan memiliki warna merah muda, aroma semangka, dengan tekstur cukup kasar, dan rasa manis khas semangka.

2. Konsentrasi pure buah semangka yang memiliki tingkat penerimaan tertinggi terhadap parameter warna, aroma, tekstur, dan rasa yaitu pada perlakuan $60 \%$. 


\section{DAFTAR PUSTAKA}

Badan Standarisasi Nasional. (1995). Standar Nasional Indonesia (SNI) No.01 37313.1995. Syarat Mutu Es Krim. Jakarta.

Badan Pengawas Obat dan Makanan. (2011). Keputusan Kepala Badan Pengawas Obat dan Makanan Republik Indonesia Nomor: HK.03.1.23.11.11.09909 Tentang Pengawasan Klaim Dalam Label dan Iklan Pangan Olahan. Jakarta: Badan Pengawas Obat dan Makanan Republik Indonesia.

Berger, K. G. (1997). Ice cream. Food Emulsions. 3rd ed. S. E. Friberg and K. Larsson, ed. Marcel Dekker, Inc., New York.

de Man, J. M. (1997). Kimia Makanan. Bandung: Penerbit ITB.

Marshall, R. T., and W. S. Arbuckle. (1996). Ice Cream. 5th ed. International Thomson Publ., New York.

McBride, R. L. and J. H. (1990). Psychological Basis of Sensory Evaluation. Elsevier Science Publisher Ltd. New York.

Nur,S.R., Panji, R, Reka,,W, Rika M, dan Cikra NHS. (2015). Perbandingan Kadar Likopen pada Manilkara zapota L., Gnetum gnemon L., Ipomoea batatas L., dan Momordica charantia L. dengan Menggunakan Campuran Solven n-Heksan, Aseton, dan Etanol, Jurnal Farmasi Sains dan Terapan, 2(1).

Nurwantoro. 2009. Bahan Ajar Dasar Teknologi Hasil Ternak. Fakultas Peternakan Universitas Diponegoro. Semarang.

Padaga, M dan M. E. Sawitri. (2005). Es Krim yang Sehat. Trubus Agrisarana. Surabaya.

Purnomo, H. (1995). Aktivitas Air dan Peranannya dalam Pengawetan Makanan. Jakarta: UIPress.

Puspitarini, R. dan A. Rahayuni. (2012). Kandungan Serat, Lemak, Sifat Fisik, dan Tingkat Penerimaan Es Krim dengan Penambahan Berbagai Jenis Bekatul Beras dan Bekatul Ketan. Journal of Nutrition College. 1 (1): 205-218.

Soekarto, T. (1995). Penilaian Organoleptik untuk Industri Pangan dan Hasil Pertanian. Bharata, Yogyakarta.

Whiting, G. C. (1995). P. Sugars. Hulme, A. C.(ed). The Biochemistry of Fruit and Their Products. Academic Press. London. (1): 1-31.

Winarno, F. G. (1997). Kimia Pangan dan Gizi. Gramedia. Jakarta. 